\title{
Analisis potensi dan tantangan dalam memajukan wisata di rawa bento Kecamatan Gunung Tujuh, Kabupaten Kerinci, Provinsi Jambi
}

\author{
Ricky Ishadi *; Johannes; Husni Hasbullah \\ Program Studi Manajemen Fakultas Ekonomi dan Bisnis Universitas Jambi \\ *E-mail korespodensi: kulukishadi@gmail.com
}

\begin{abstract}
This study aims to analyze the strengths, weaknesses, opportunities, and threats of BUMDES Jernih Jaya in developing the natural tourism object of Rawa Bento, Kerinci Regency, Jambi Province. Then formulate a strategy for development by minimizing weaknesses and threats, maximizing utilization of opportunities and strengths. Data was collected through literature study, observation, and interviews with stakeholders, namely BUMDES and village heads. The data were analyzed descriptively and then to determine the strategy for developing natural attractions in Bento Swamp. A SWOT analysis was carried out. Based on the results of the research, it can be concluded that the strategy for developing natural attractions in Rawa Bento includes building infrastructure such as road access, transportation means, and accommodation facilities, making tourist attractions and promoting tourism objects, developing tourism products, and involving the community in tourism management.
\end{abstract}

Keywords: SWOT analysis, Rawa Bento, tourism

\begin{abstract}
Abstrak
Penelitian ini bertujuan untuk menganalisis kekuatan, kelemahan, peluang dan ancaman BUMDES Jernih Jaya dalam mengembangkan objek wisata alam Rawa Bento Kabupaten Kerinci, Provinsi Jambi. Kemudian dirumuskan strategi untuk pengembangan dengan cara meminimalkan kelemahan dan ancaman, memaksimalkan pendayagunaan peluang dan kekuatan. Data dikumpulkan melalui studi kepustakaan, observasi serta wawancara dengan stakeholder yaitu BUMDES dan Kepala Desa. Data dianalisis secara deskriptif kemudian untuk menentukan strategi pengembangan objek wisata alam Rawa Bento dilakukan dengan analisis SWOT. Berdasarkan hasil penelitian maka dapat disimpulkan strategi pengembangan objek wisata alam Rawa Bento antara lain membangun sarana prasarana seperti akses jalan, alat angkut dan sarana akomodasi, membuat atraksi wisata dan promosi obyek wisata, mengembangkan produk wisata, serta melibatkan masyarakat dalam pengelolaan wisata.
\end{abstract}

Kata kunci: analisis SWOT, Rawa Bento, pariwista

\section{PENDAHULUAN}

Pada saat ini, objek wisata yang berada di daerah perdesaan telah menjadi salah satu sumber daya potensial yang menjanjikan dan memiliki prospek yang bagus untuk dikembangkan karena memiliki potensi yang kuat untuk menarik wisatawan, khususnya wisatawan dari daerah perkotaan. Desa yang memiliki alam yang indah dan juga budaya 
yang kental menjadi daya tarik tersendiri bagi wisatawan yang mayoritas merupakan masyarakat perkotaan. Masyarakat perkotaan yang setiap harinya berhadapan dengan kemacetan, hiruk pikuk kota dan sejumlah permasalahan perkotaan lainnya tentu menganggap desa merupakan suatu tempat yang tepat untuk resfreshing.

Beberapa faktor inilah yang belakangan ini membuat desa menjadi sangat potensial untuk dikembangkan sebagai objek wisata. Pariwisata yang berbasis di pedesaan juga turut berperan serta dalam meningkatkan perekonomian serta meningkatkan kesejahteraan masyarakat yang ada di lokasi itu sendiri. Kesejahteraan masyarakat akan meningkat seiring dengan semakin majunya pariwisata yang ada karena pariwisata ini akan mendorong aspek sosial serta ekonomi untuk ikut berkembang (Mahmoudi, et al, 2011).

Pengembangan desa menjadi suatu objek wisata sangat berkaitan erat dengan peran serta masyarakat lokal. Hal ini dikarenakan pada suatu desa wisata, wisatawan tidak hanya butuh untuk mengunjungi tetapi juga butuh untuk berinteraksi dan melakukan berbagai aktivitas bersama masyarakat lokal agar mendapatkan sejumlah pengalaman. Wisata yang menggunakan peran aktif masyarakat dalam pengembangannya ini biasa disebut Community Based Tourism (CBT). Definisi Community Based Tourism (CBT) adalah suatu kegiatan wisata yang dilakukan untuk mendapatkan unsur-unsur pengalaman, keunikan dan keaslian dari kelangsungan budaya, sosial dan lingkungan yang ada di daerah tersebut. Bentuk pariwisata ini dikelola dan dimiliki oleh masyarakat guna membantu wisatawan meningkatkan kesadaran mereka dan belajar tentang tata cara hidup masyarakat lokal. Community Based Tourism (CBT) merupakan model pengembangan pariwisata yang berasumsi bahwa pariwisata harus berangkat dari kesadaran nilai-nilai kebutuhan masyarakat sebagai upaya membangun pariwisata yang lebih bermanfaat bagi kebutuhan, inisiatif dan peluang masyarakat local (Đurkin\& Perić, 2017).

Salah satu objek wisata yang berada di provinsi Jambi adalah Rawa Bento yang berada di Kabupaten Kerinci.Kabupaten Kerinci khususnya sektor pariwisata merupakan salah satu sektor strategis dan potensial untuk dikelola, dikembangkan dan dipasarkan. Rawa Bento yang terletak di Kecamatan Gunung Tujuh merupakan destinasi baru yang dikembangkan oleh masyarakat melalui Bumdes (Badan Usaha Milik Desa) dengan menggunakan dana desa. Rawa ini merupakan lahan basah pada ketinggian 1.333 mdpl, dengan luas sekitar 1.000 ha. Kawasan ini awalnya adalah danau, menampung aliran sungai yang berasal dari gugusan pesona wisata Ja mbi Gunung Kerinci. Meskipun baru dipopulerkan, Rawa Bento ini sudah mulai ditawarkan dalam paket wisata Kerinci teruatama untuk wisatawan yang ingin menikmati keindahan ekosistem perairan

Permasalahan yang terjadi pada pariwisata daerah adalah munculnya persaingan antara objek wisata lain, baik dari daerah tersebut ataupun dari luar daerah. Ketatnya persaingan suatu desa biasa yang dijadikan suatu desa wisata saat ini apabila diimbangi dengan manajemen kinerja yang baik akan membuat desa wisata menjadi semakin maju dan berkembang, begitu pula sebaliknya. Hal ini dapat dilihat dari jumlah desa wisata yang ada di Kabupaten Kerinci dan Kabupaten lainnya di Provinsi Jambi yang semakin betambah. Semakin banyak pula persaingan antar desa wisata dalam hal sarana dan prasarana serta segala macam inovasi-inovasi baru yang mencakup kegiatan atau fasilitas yang disediakan oleh desa wisata lain, sehinga diperlukan suatu strategi pengembangan yang tepat untuk diterapkan pada Desa Jernih Jaya ini agar tidak kalah dengan desa wisata lain (Hasil Wawancara dengan staff Dinas Pariwisata Kabupaten Kerinci, Pada 31 Juli 2019). 
Penelitian yang berkaitan dengan strategi pariwasata telah dilakukan oleh beberapa peneliti. Penelitian Kurniawan (2015), menyatakan beberapa hal yang perlu di pehami dalam mengatur strategi pemasaran objek wisata. Pertama perlu diperhatikan dalam memajukan pariwisata alam pedesaan adalah mengadakan variasi pada outbond-outbond yang telah menjadi daya tarik wisatawan sehingga pengunjung memiliki keinginan untuk kembali lagi. Bermula dari banyaknya pengunjung yang ingin menikmati fasilitas yang ditawarkan oleh tempat wisata Umbul Sidomukti. Kedua. untuk pemerintah Kabupaten, untuk memperbaiki kondisi jalan yang menjadi akses utama bagi para wisatawan untuk menuju objek wisata, sehingga pengunjung mudah untuk sampai ke tempat tujuan. Penelitian Lincinwa (2018), menyatakan ada beberapa strategi pengembangan yang dapat dilakukan oleh pemerintah. Pertama,meningkatkan promosi objek wisata, pemasaran atau promosi dan inovasi kegiatankegiatan pariwisata penting untuk dilakukan karena hal tersebut dapat menarik minat wisatawan untuk berkunjung. Kedua,meningkatkan sarana dan prasarana serta infrastruktur yang menunjang seperti pembangunan wahana permainan air, outbond, gardu pandang, kereta wisata dan fasilitas- fasilitas penunjang lainnya sehingga menarik dan memberi kenyamanan bagi pengunjung.

Penentuan strategi pariwisata tidak bisa dilakukan secara instan, perlu adanya kajian yang mendalam sehingga dapat memberikan rekomendasi strategi yang sesuai dengan kondisi objek wisata. Analisa SWOT merupakan salah satu metode untuk menggambarkan dan mengevaluasi suatu masalah, proyek atau konsep bisnis yang berdasarkan faktor eksternal dan internal. Analisis SWOT menggambarkan situasi yang terjadi bukan pemecahan suatu masalah (Rangkuti,3.2014).Dalam usaha mendukung manajemen pengambilan keputusan, analisis SWOT memiliki peran besar didalamnya. Berbagai kalangan mempercayai jika analisis dengan menggunakan prespektif SWOT telah dianggap memiliki keunggulannya. Kegunaan tersebut berupa mampu memberikan gambaran suatu dari empat sudut dimensi, yaitu kekuatan (strength) dan kelemahan (weakness), serta peluan (opportunities) dan ancaman (threats) sehingga pengambilan keputusan bisa melihat dari empat dimensi ini secara komprehensif dan dapat memberikan pemahaman kepada pada stakeholder's yang berkeinginan menaruh simpati bahkan bergabung dalam pengembangan objek wisata (Suhartini, 2012).

Berkaitan dengan permasalahan tersebut, tujuan dari penelitian ini adalah mengetahui dan mempelajari bagaimana strategi pemasaran yang diterapkan oleh perangkat desa dan BUMDES Rawa Bento dalam mengembangan Objek wisata Rawa Bento Rawa Bento di kabupaten Kerinci Provinsi Jambi. Diharapkan penelitian yang dilakukan ini bisa memberikan rekomendasi terbaik bagi pihak perangkat desa dan BUMDES Rawa Bento memajukan objek wisata yang dikelola.

\section{TINJAUAN PUSTAKA}

\section{Pariwisata}

Objek wisata adalah segala sesuatu yang memiliki keunikan, keindahan dan nilai yang berupa keanekaragaman kekayaan alam, budaha dan hasil buatan manusia yang menjadi sasaran atau tujuan kunjungan wisatawan. Menurut Arisany (2016) objek wisata merupakan perwujudan daripada ciptaan manusia, tata hidup, seni budaya, sejarah bangsa dan tempat atau keadaan alam yang mempunyai daya tarik untuk dikunjungi (Ridwan, 2012). 
Istilah pariwisata berasal dari dua suku kata, yaitu "pari" dan "wisata". Pari berarti banyak, berkali-kali atau berputar-putar, sedangkan wisata berarti perjalanan atau bepergian. Jadi pariwisata adalah perjalanan yang dilakukan berkali-kali atau berputar-putar dari suatu tempat ke tempat yang lain. Berangkat dari hal inilah kemudian pariwisata diartikan sebagai suatu perjalanan terencana yang dilakukan, baik secara individu atau kelompok, dari satu tempat ke tempat lain dengan tujuan untuk mendapatkan kepuasan dan kesenangan (Sinaga, 2010).

\section{Daya tarik pariwisata}

Daya tarik wisata yang tidak atau belum dapat disebut sebagai daya tarik wisata, sampai adanya suatu jenis pengembangan tertentu. Objek dan daya tarik wisata merupakan dasar bagi kepariwisataan. Tanpa adanya daya tarik di suatu daerah atau tempat tertentu, kepariwisataan sulit untuk dikembangkan. Menurut Maryani (2005) suatu objek wisata dapat menarik untuk dikunjungi oleh wisatawan harus memenuhi syarat- syarat untuk pengembangan daerahnya, syarat-syarat tersebut adalah:

What to See, Di tempat tersebut harus ada objek wisata dan atraksi wisata yang berbeda dengan yang dimiliki daerah lain. Dengan kata lain daerah tersebut harus memiliki daya tarik khusus dan atraksi bidaya yang dapat dijadikan "entertaiment" bagi wisatawan. What to see ini dapat meliputi pemandangan alam, kegiatan kesenian, dan atraksi wisata yang ada di dalam daerah wisata tersebut.

What to Do, Di tempat tersebut selain banyak yang dapat dipilih dan disaksikan, harus disediakan fasilitas rekreasi dan kegiatan wisata yang dapat membuat wisatawan betah tinggal lama di tempat itu.

What to Buy, Tempat tujuan wisata harus tersedia fasilitas untuk berbelanja terutama barang souvenir dan kerajinan khas rakyat setempat sebagai oleh-oleh untuk di bawa pulang ke tempat asal wisatawan.

What to Arrived, Di dalamnya termasuk aksesibilitas, bagaimana kita mengunjungi objek wisata tersebut, moda transportasi apa yang akan digunakan dan berapa lama tiba ketempat tujuan wisata tersebut.

What to Stay, Bagaimana wisatawan akan tinggal untuk sementara selama dia berlibur di objek wisata itu. Diperlukan penginapan-penginapan baik hotel berbintang atau hotel non berbintang dan juga homestay-homestay yang memanfaatkan rumah tempat tinggal masyarakat sekitar.

\section{Strategi pemasaran}

Strategi merupakan tindakan yang bersifat incremental (senantiasa meningkat) dan terus- menerus, serta dilakukan berdasarkan sudut pandang tentang apa yang diharapkan oleh para pelanggan di masa depan. Dengan demikian, strategi hampir selalu dimulai dari apa yang dapat terjadi dan bukan dimulai dari apa yang terjadi. Saat ini ada sebuah pencampuradukkan kata antara strategi dengan taktik. Dalam hal pengertian, taktik bukanlah sebuah strategi, namun taktik ada di dalam strategi. Taktik ini memiliki ruang lingkup yang lebih kecil dengan waktu yang lebih singkat

Menurut Kotler \& Armstrong (2012) Pemasaran adalah proses dimana perusahaan menciptakan nilai bagi pelanggan dan membangun hubungan yang kuat dengan pelanggan dengan tujuan untuk menangkap nilai dari pelanggan sebagai imbalannya. Pengertian diatas dapat disimpulkan bahwa pemasaran adalah kegiatan merencanan, 
pengorganisasi serta kegiatan untuk memuaskan kebutuhan dan keinginan pelanggan dengan tujuan untuk memperoleh suatu laba.

Kotler \& Armstrong (2012) Menyatakan bahwa pencapaian tujuan organisasi tergantung pada pengetahuan akan kebutuhan dan keinginan target pasar dan memberikan kepuasan yang diinginkan dengan lebih baik daripada pesaing. Konsep pemasaran adalah filosofi merasakan dan merespon yang berpusat pada pelanggan. Konsep ini bukanlah menemukan pelanggan yang tepat untuk produknya tetapi menemukan produk yang tepat bagi suatu pelanggan.

\section{METODE}

Ditinjau dari jenis datanya pendekatan penelitian yang digunakan dalam penelitian ini adalah pendekatan kualitatif. Jenis penelitian yang digunakan adalah penelitian deskriptif yaitu penelitian yang berusaha untuk menuturkan pemecahan masalah yang ada sekarang berdasarkan data-data. Jenis penelitian deskriptif kualitatif yang digunakan pada penelitian ini dimaksudkan untuk memperoleh informasi mengenai strategi pemasaran yang dilakukan oleh Bumdes Desa dalam mengelola objek wisata Rawa Bento, Kabupaten Kerinci, Jambi. Penentuan imforman dalam penelitian ini berdasarkan kriteria yang dikemukan oleh Miles dan Huberman (dikutip dalam Sapriya, 2007) yaitu: latar (settings), para pelaku (actors), peristiwa-peritiwa (events), dan proses (proocess). Adapun informan dalam penelitian adalah kepala BUMDES Pengelola objek wisata Rawa Bento. Teknik analisis data yang digunakan dalam penelitian ini adalah menggunakan langkah-langkah seperti yang dikemukakan oleh Burhan Bungin (2003), yaitu pengumpulan Data (Data Collection), reduksi Data (Data Reduction), penyajian Data (Display Data), dan verifikasi dan Penegasan Kesimpulan (Conclution Drawing and Verification)

\section{HASIL DAN PEMBAHASAN}

\section{Gambaran umum desa jerni jaya dan rawa bento}

Jernih Jaya adalah sebuah desa di wilayah Kecamatan Gunung Tujuh, Kabupaten Kerinci, Provinsi Jambi, Indonesia. Desa Jernih Jaya merupakan sebuah desa di wilayah kecamatan gunung tujuh,kabupaten kerinci, Provinsi Jambi. Nama desa jernih jaya, dikarenakan dengan aliran sungai air gunung tujuh yang jernih dan sampai saat ini jumlah penduduk yang ada di desa jernih jaya sekitar 1800 jiwa, itu belum di rekap rincian yang baru karena penduduk seperti ada yang meninggal dan hamill. Berikut ini adalah batas administrative desa Jernih Jaya.

Bagian barat gunung kerinci,Bagian timur desa sungai jernih,Bagian selatan desa bumbu duri,Bagian utara desa lubuk pauh

Rawa Bento terletak d Desa Jernih Jaya, Kecamatan Gunung 7, Kabupaten Kerinci, Provinsi Jambi. Rawa ini merupakan lahan basah pada ketinggian 1.333 mdpl, dengan luas sekitar 1.000 ha. Kawasan iniawalnya adalah danau, menampung aliran sungai yang berasal dari gugusan Pesona Wisata Jambi Gunung Kerinci, Gunung Tujuh, Gunung Sangkar dan sekitarnya. Karena pendangkalan, danau lama-lama menjadi rawa. Rawa ini tertutup oleh rumput bento dan menjadi hutan rawa, sehingga dikenal dengan nama Rawa Bento. Tak hanya keunikan rawanya yang ditumbuhi vegetasi menjadi pemandangan yang indah, tetapi juga beberapa jenis burung yang hidup di daerah ini. Antara lain burung jernih, burung layang-layang dan putih, bebek liar dan lain sebagainya. 


\section{Strategi Pemasaran Rawa Bento}

Formulasi strategi ini dilakukan dengan menggunakan matriks SWOT. Matriks SWOT Desa Rawa Bento dapat dilihat pada Tabel 1

Tabel 1. Analisis SWOT

Opportunities (O)

yang menjadi desa wisata

semakin berkembang dan

semakin diminati masyarakat

Menyerap tenaga kerja di

daerah sekitar desa Rawa Bento

sehingga dapat mengurangi

pengangguran

3. Meningkatnya kegiatan

ekonomi bagi warga akan

meningkatkan kesejahteraan

masyarakat sekitar

Keberadaan Perguruan Tinggi

dengan Lembaga Penelitian dan guna meningkatkan minat

Pengabdian Masyarakat sebagai pengunjung

mitra masyarakat dan

pemerintah

Berkembangnya teknologi

informasi melalui media

elektronik sebagai media untuk

memasarkan program- program wisata

yang

handal dan berkualitas.

Menyiapkan sarana dan prasarana pendukung

yang lebih menarik bagi

pengunjung

bertemakan alam terbuka

desa Nongkosawit dan

\section{Strengths (S) \\ Struktur organisasi berjalan \\ dengan baik \\ Partisipasi masyarakat dalam}

Weaknesses (W)

Desa Rawa Bento berada dalam

zona bahaya gunung merapi

karena hanya berjarak $15 \mathrm{~km}$ dari

mendukung pengembangan desa puncak merapi

Rawa Bento sangat kuat
Potensi yang dimiliki desa

Rawa Bento banyak dan

beragam

Pemandangan alam yang indah, masih kurang

berhawa sejuk dan asri

Ketersediaan sarana prasarana

dan fasilitas cukup memadai

Strategi S-O

Promosi tentang desa Rawa

Bento belum maksimal

Kualitas sumber daya manusia

masyarakat desa Rawa Bento

Pengelolaan manajemen

keuangan desa Rawa Bento

kurang

maksimal

Kurangnya dana operasional untuk pengembangan desa Rawa

Bento

\section{Strategi W-O}

. Memperbaiki sistem

manajemen

untuk mengatur keuangan desa.

Meningkatkan kualitas sumber

daya manusia

Membuat objek wisata yang

Mempertahankan kualitas alam Lembaga Penelitian dan

Pengabdian Masyarakat

Memanfaatkan sponsor seperti

Keberadaan Perguruan Tinggi dengan Lembaga Penelitian dan Pengabdian Masyarakat untuk memperbaiki masalah pedanaan.

Memanfaatkan lembaga penelitian untuk mendeteksi secara dini jika terjadi ancaman dari gunung berapi 
Tingginya pembiayaan dalam penyelenggaraan kegiatan desa wisata yang dirasakan memberatkan masyarakat berkualitas dan kreatif untuk mengatasi masalah persaingan.

Berdasarkan analisis SWOT diatas, wisata Rawa Bento harus menerapkan strategi berdasarkan kekuatan yang dimiliki untuk memaksimalkan peluang sebesar-besarnya, sehingga pada matriks SWOT strategi yang harus diterapkan strategi sebagai berikut:

Meningkatkan kualitas partisipasi pelayanan masyarakat terhadap wisatawan. Dalam pengembangan desa wisata Rawa Bento, dengan meningkatkan kualitas pelayanan yang baik, maka akan memberikan kepuasan bagi wisatawan yang datang. Kepuasan wisatawan yang datang akan membuat wisatawan untuk kembali lagi berkunjung. Peningkatan kualitas pelayanan ini dimulai dari pelayanan penerimaan tamu, pemandu wisata, pelayanan homestay sampai kepergian tamu. Contohnya dalam pelayanan homestay, masyarakat yang tempat tinggalnya dijadikan homestay dapat memberikan fasilitas yang sesuai dengan keinginan wisatawan, kemudian dalam pelayanan pemandu, pemandu harus bisa memberikan kenyamanan dan keamanan bagi wisatawan serta harus dapat menjawab berbagai pertanyaan dari wisatawan yang ingin mengtahui berbagai hal tentang desa wisata Rawa Bento.

Meningkatkan dan mempertahankan daya tarik wisata yaitu dengan menggali semua potensi-potensi yang ada di desa wisata Rawa Bento kemudian dikemas sehingga menjadikan sebuah produk wisata yang menarik bagi wisatawan.Seperti di bidang peternakan, perikanan, dan kesenian. Dengan menggali kembali potensi yang dimiliki desa wisata Rawa Bento yang tidak dimiliki oleh desa wisata lain. Seperti wisata melukis yang merupakan kegiatan dan objek wisata pertama yang disuguhkan oleh desa wisata Rawa Bento dengan sanggar lukis yang diberi nama "Sanggar Pratista". Sanggar ini mengajarkan pengunjung dan masyarakat desa cara melukis yang baik, seperti : melukis dengan media kertas, gerabah, kaos, caping, dan kanvas. Hasil karya dari pengelola, pengunjung, dan masyarakat desa dipamerkan di sekitar desa wisata.Mempertahankan daya tarik wisata adalah tindakan pelestarian keanekaragaman potensi yang ada sebagai ciri khas bagi desa wisata tersebut sehingga menarik wisatawan yang datang.

Peningkatan variasi produk penunjang wisata asli buatan masyarakat sekitar Produkproduk wisata berkualitas yang dimaksud adalah wisatawan yang berkunjung tidak hanya merasakan kesenangan saja namun juga mendapatkan pengetahuan mengenai kebudayaan, kesenian, kerajinan dan lain-lain.Serta memberikan rasa aman dan nyaman ketika pengunjung.Segala potensi yang dimiliki oleh desa perlu digali dan dikemas semenarik mungkin dengan memanfaatkan berbagai sumber daya yang dimiliki dan didukung dengandata yang akurat, informasi lengkap, kesiapan sumberdaya manusia pelaksana, membuat paket wisata, danlain-lain. Meningkatkan promosi/pemasaran dengan memanfatkan kemajuan teknologi. Promosi pariwisata merupakan salah satu sektor promosi terpenting yang harus selalu mengalami penataan ulang oleh para pengelola, karena promosi berkaitan erat dengan kelangsungan siklus produk yang akan dipasarkan. Untuk meningkatkan jumlah pengunjung maka sangat diperlukan promosi dengan memanfatkan kemajuan teknologi.Dalam meningkatkan promosi pengelola dapat memanfaatkan kemajuan teknologi baik dengan media cetak, seperti brosur maupun teknologi dengan pembuatan website, facebook, twitter, blog, instagram, path, serta melakukan promosi di sekolah, universitas, dan lembaga yang lainnya.Untuk saat ini dan kedepannya instagram dapat dijadikan strategi marketing yang jitu dalam mempromosikan berbagai keindahan desa wisata Rawa Bento.Cara penggunaan yang mudah dan tidak memerlukan biaya yang 
besar, dengan menekankan pada bentuk visual atau gambar, adanya fitur hashtag yang mempermudah pencarian, dan jumlah pengguna yang cepat meningkat.

Meningkatkan dan mengembangkan sarana prasarana dan fasilitas pendukung desa wisata

Ketersediaan fasilitas dan sarana prasarana menjadi faktor yang penting dalam pengembangan pariwisata. Semakin memadai fasilitas dan sarana prasarana yang ada disuatu obyek wisata akan berdampak pada semakin tingginya tingkat kunjungan wisatawan. Dengan tingginya tingkat kunjungan wisatawan akan berdampak pada semakin tingginya pendapatan dari obyek wisata. Fasilitas pendukung dapat berupa homestay, MCK, masjid, dan lahan parkir.Masyarakat yang tempat tinggalnya dijadikan homestay harus mengetahui standar homestay yang baik dan benar, seperti adanya sanitasi, tingkat pencahayaan yang cukup, air yang bersih, kamar mandi yang menempel dengan rumah.Mengembangkan fasilitas pendukung desa wisata dengan perbaikan jalan, menambah papan petunjuk menuju desa wisata, serta pembuatan jalan alternatif menuju desa wisata.Di desa wisata juga perlu menambah jumlah MCK dan dijaga kebersihannya.Mengoptimalkan lahan parkir, karena lahan parkir yang ada kurang memadai.

\section{KESIMPULAN DAN SARAN}

\section{Kesimpulan}

Berdasarkan di data yang didapat, meskipun rawa bento menghadapi berbagai ancaman seperti terjadi bencana/gangguan alam berupa erupsi Gunung Merapi, kurangnya alat transportasi umum menuju desa Rawa Bento, budaya yang kurang baik yang mungkin dibawa oleh wisatawan yang berkunjung, munculnya kompetitor desa wisata yang bertindak curang dengan menjiplak atraksi dan paket wisata yang ditawarkan, dan tingginya pembiayaan dalam penyelenggaraan kegiatan desa wisata. Namun, objek wisata Rawa Bento masih memiliki kekuatan internal sehingga strategi yang harus diterapkan adalah menggunakan kekuatan untuk memanfaatkan peluang jangka panjang dengan cara strategy diversifikasi (produk/pasar).

\section{Saran}

Diharapkan bagi Bagi pihak Bumdes Rawa Bento, diupayakan bisa melakukan kerja sama dengan berbagai pihak baik pemerintah daerah ataupun swasta (seperti Bank 9 Jambi, BNI, ataupun perusahaan swasta lainnya) untuk mengembangkan objek wisata Rawa Bento.

\section{DAFTAR PUSTAKA}

Baud-Bovy, M., \& Lawson, F. (1998). Pariwisata dan rekreasi: buku pegangan perencanaan dan desain . Butterworth-Heinemann Ltd.

Carrà, G., Mariani, M., Radi, I., \& Peri, I. (2016). Analisis strategi partisipatif: Kasus bisnis wisata anggur. Procedia ilmu pertanian dan pertanian , 8 , 706-712.

urkin, J., \& Perić, M. (2017). Pengorganisasian pariwisata berbasis masyarakat: Membandingkan sikap penduduk lokal dan pengusaha pariwisata lokal di Ravna Gora, Kroasia. Ekonomi Lokal, 32 (7), 678-691. 
Suryatama, E. (2014). Lebih Memahami Analisis SWOT dalam Bisnis. Penerbit Kata Pena. Surabaya.

Haryani, D. (2020).Studi Kelayakan Wisata Kampung 99 Pepohonan Sebagai Daerah Tujuan Wisata di Kecamatan Limo Kota Depok. Skripsi, Jakarta: FITK UIN Syarif Hidayatullah Jakarta.

Haryani, H. (2014). Potensi pengembangan atraksi wisata kampung nelayan pasie nan tigo Kota Padang Ditengah Ancaman Bencana Abrasi dan Banjir. MIMBAR: Jurnal Sosial dan Pembangunan, 30(2), 189-198.

Haryani, H., \& Utama, L. (2016). Revitalization of coastal area pasie nan tigo padang city for hazard mitigation. MIMBAR: Jurnal Sosial dan Pembangunan, 32(1), 49-57.

Shabrina, P. (2020). Pengaruh perceived destination image dan attribute perception terhadap tourist satisfaction serta intention to recommend (studi pada wisatawan yang telah berkunjung ke Candi Prambanan, Yogyakarta. Doctoral dissertation, UPN" Vteran" Yogyakarta

Irawan, K. (2010). Potensi obyek wisata sebagai daya tarik wisata. Yogyakarta: Kertas Karya.

Inskeep, E. (1991). Perencanaan pariwisata: Pendekatan pembangunan yang terintegrasi dan berkelanjutan. John Wiley \& Sons.

Damayanti, C. T. (2019). Peran BUMDES dalam pengembangan desa wisata pujon kidul. Doctoral dissertation, University of Muhammadiyah Malang).

Kurniansah. (2014). Penilaian wisatawan terhadap potensi objek wisata, Alfabeta: Bandung.

Kurniawan, W. (2017). Dampak sosial ekonomi pembangunan pariwisata Umbul Sidomukti Kecamatan Bandungan Kabupaten Semarang. Economics Development Analysis Journal, 4(4), 443-451.

Kusumaningrum, D. (2009). Persepsi wisatawan nusantara terhadap daya tarik wisata di Kota Palembang Doctoral dissertation, Universitas Gadjah Mada.

Krisdayanti, K., Achmad, GN, \& Wasil, M. (2020). Pengaruh e-marketing, features dan design terhadap kepuasan pengguna whatsapp di kecamatan samarinda utara. Jurnal Ilmu Manajemen Mulawarman (JIMM) , 4 (2).

Mahmoudi, B., Haghsetan, A., \& Maleki, R. (2011). Investigasi hambatan dan strategi pengembangan desa wisata menggunakan Matriks SWOT. Jurnal Pembangunan Berkelanjutan , 4 (2), 136.

Maryani, E. (1991). Pengantar geografi pariwisata. Bandung: Jurusan Pendidikan Geografi FPIPS IKIP.

Muljadi, A. J. (2012). Kepariwisataan dan Perjalanan: Cetakan ketiga. Jakarta: Rajagrafindo Persada.

Sariisik, M., Turkay, O., \& Akova, O. (2011). Bagaimana mengelola pariwisata kapal pesiar di Turki: Analisis swot dan strategi terkait. Procedia-Sosial dan Ilmu Perilaku, 24 , 1014-1025.

Ihkamuddin, M. (2020). Pengaruh promosi, kualitas produk, dan harga terhadap keputusan pembelian pada Shopee Marketplace serta tinjauannya dari sudut pandang islam:(studi pada mahasiswa Fakultas Ekonomi dan Bisnis Universitas Yarsi. Doctoral dissertation, Universitas YARSI.

Sugiyono, S. (2010). Metode penelitian kuantitatif dan kualitatif dan R\&D. Alfabeta Bandung. 
Hidayatuloh, S. (2020). Analisis strategi pemasaran jasa perbaikan dan instalasi ac mobil dengan menggunakan metode malcolm baldrige pada PT Mitra Enviro Nusantara. Ikra-Ith Ekonomika, 3(3), 36-44.

Suryatama, E. (2014). Lebih memahami analisis SWOT dalam Bisnis. Penerbit Kata Pena. Surabaya.

Zhang, X. (2012). Penelitian tentang strategi pengembangan desa wisata di Suzhou berdasarkan analisis SWOT. Procedia Energi , 16 , 1295-1299. 